\title{
Archaeoseismic record at the ancient Roman City of Baelo Claudia (Cádiz, south Spain)
}

\author{
P.G. Silva ${ }^{\text {a,* }}$, F. Borja ${ }^{\text {b }}$, C. Zazo ${ }^{\text {c }}$, J.L. Goy ${ }^{\text {d }}$, T. Bardají $^{\text {e }}$, L. De Luque $^{\text {c }}$, \\ J. Lario ${ }^{\mathrm{f}}$, C.J. Dabrio ${ }^{\mathrm{g}}$ \\ ${ }^{a}$ Depto. Geología Universidad Salamanca, Escuela Politécnica Superior de Avila, 05003-Avila, Spain \\ ${ }^{\mathrm{b}}$ Area Geografia Física, Facultad de Humanidades, Universidad de Huelva 21007-Huelva, Spain \\ ${ }^{\mathrm{c} D e p t o .}$ Geología, Museo Nacional CC. Naturales, CSIC, C/ José Gutiérrez Abascal, 2, 28006-Madrid, Spain \\ ${ }^{\mathrm{d}}$ Depto. Geología, Facultad de Ciencias, Universidad Salamanca, 37008-Salamanca, Spain

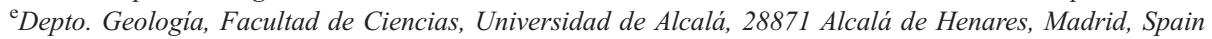 \\ ${ }^{\mathrm{f}}$ Area Geodinámica, Fac. Ciencias del Medioambiente, Univ. Castilla-La Mancha, 45071-Toledo, Spain \\ ${ }^{\mathrm{g}}$ Depto. Estratigrafia, Facultad Ciencias Geológicas, UCM, 28040-Madrid, Spain
}

Received 1 October 2001; accepted 31 May 2005

Available online 16 August 2005

\begin{abstract}
This study represents the first paleoseismic approach in Spain in which archaeological remains are considered. The ancient Roman city of Baelo Claudia (1st-4th centuries AD), located at the axial zone of the Gibraltar Strait (Cadiz, south Spain), contains abundant disrupted architectural relics and ground collapses (i.e. landsliding, liquefacion) probably related to historic earthquake damage of intensity IX-X MSK. The archaeological stratigraphy of the city evidence two major episodes of abrupt city destruction bracketed in AD 40-60 and AD 350-395 separated by an intervening horizon of demolition for city rebuilding, otherwise characteristic for many earthquake-damaged archaeological sites in the Mediterranean. The second episode led the eventual city abandonment, and it is evidenced by good examples of column collapse, distortion, failure and breakdown of house and city walls, and pavement warping and disruptions documented during different archaeological excavations, which can be catalogued as secondary coseismic effects. Main damaged relicts observable today are the set of pop-up like arrays and warping developed in the ancient Roman pavement. Their analysis indicate an anomalous westwards ground displacement oblique to the main gentle southward slope of the topography, as also evidence failures, collapses and breakdown of walls and columns, suggesting that stress acted in a broad SW-NE/WSW-ENE orientation consistent whit the expectable motion along the largest NE-SW strike-slip faults of the zone, which in turn can be catalogued as seismic sources of moderate events (ca. 5 $\mathrm{mb}$ ). Major disruptions and city abandonment were hesitantly related to relatively far strong earthquakes occurred during the late 4th century AD in the Mediterranean or western coast of Iberia by Menanteau et al. [Menanteau, L., Vanney, J.R., Zazo, C., 1983. Belo II : Belo et son environment (Detroit de Gibraltar), Etude physique d'un site antique. Pub. Casa de Velazquez, Serie Archeologie 4., Ed. Broccard, París.]. However, this study indicates that the occurrence of close moderate earthquakes jointly
\end{abstract}


with the unstable character of the ground at the zone (site effect) is a more reliable hypothesis to explain the observed deformations.

Keywords: Archeoseismology; Paleoseismicity; Unstable ground; Betic Cordilleras; Spain

\section{Introduction}

Faulted and disturbed architectural relicts can be used as valuable markers for late Quaternary tectonics and paleoseismicity. Most of the works reporting earthquake damage at archaeological sites are mainly related to ancient populated areas in the Eastern Mediterranean region such as Greece and Italy (Stiros, 1988, 1996; Stiros and Papageourgiu, 2001; Guidoboni et al., 1994,), Israel (Karcz and Kafri, 1978; Marco et al., 1997), Turkey (Hancock and Altunel, 1997; Altunel et al., 2003; Similox-Tohon et al., 2002), and Syria (Meghraoui, 2002). In contrast, ancient earthquake evidence lacks for the western Mediterranean. This paper presents probable evidence of seismic damage in the ancient Roman city of Baelo Claudia (1st to 4th centuries AD) located in the westernmost part of the Mediterranean at the Gibraltar Strait (Cádiz, south Spain).

The archaeological record of this ancient Roman city highlight the occurrence of two major episodes of abrupt city destruction, which are still weakly understood from single archaeological and historical approaches (Sillières, 1997). The first episode (AD 40-60) is poorly documented but was followed by the development of a horizon of demolition and city rebuilding (Sillières, 1995). The second episode (AD 350-395) led the abrupt ruin of the city and its eventual abandonment (Menanteau et al., 1983). This last episode is well documented all along the ancient monumental zone of the city, including outstanding examples of pavement warping and disruptions, columns collapse, distortion, failure and breakdown of house and city walls and large block falls. Earlier studies (Menanteau et al., 1983) tentatively related this last episode to seismic damage promoted by strong far earthquakes, as those recorded in the north African coast, the San Vicente Cape, or even in the Eastern Mediterranean (i.e. 365 AD Crete Event). Nevertheless, aside the publication of short reports focussed on the occurrence of pavement pop- up like structures and ground instability around the city (Borja et al., 1993; Goy et al., 1994), any comprehensive analysis exploring the seismic hypothesis has been published yet.

The aims of this study are focused in: (1) the analysis of the set of archaeological relicts disturbances and ground deformations for their characterization and classification as true coseismic features (or not); (2) the study of the regional seismotectonics and recent faulting evidence around the city for the evaHration of the seismic potential of the existing faults, hd the exploration of the reliability of far strong earthquake versus moderate close ones as probable causative events; and (3) the analysis of the urban geology and available geotechnical data in order to test if the expectable ground response of the Roman site could induce the observed deformations in the context of the different seismic scenarios listed in the Spanish Seismic Code NCS-94 (1995).

\section{Neotectonic and seismotectonic setting of Baelo Claudia}

\subsection{Neotectonics}

Baelo Claudia is located in the axial zone of the Gibraltar Strait (south Spain), the westernmost termination of the Mediterranean Alpine Chain at the Betic Cordillera. This region is currently under a NNWSSE compression induced by the convergence of the African and Eurasian plates (Westaway, 1990). This stress field engineered the generation of two conjugated major strike-slip systems defined by NE-SW sinistral faults and NW-SE dextral ones (Fig. 1) which constitute large inland morpho-tectonic lineaments (up to $22 \mathrm{~km}$ length). A roughly E-W tectonic expulsion of crustal blocks took place along these master faults, triggering the development of $\mathrm{N}-\mathrm{S}$ normal faulted-bounding sedimentary troughs (Fig. 1) since the Late Miocene-Pliocene times (Goy et 


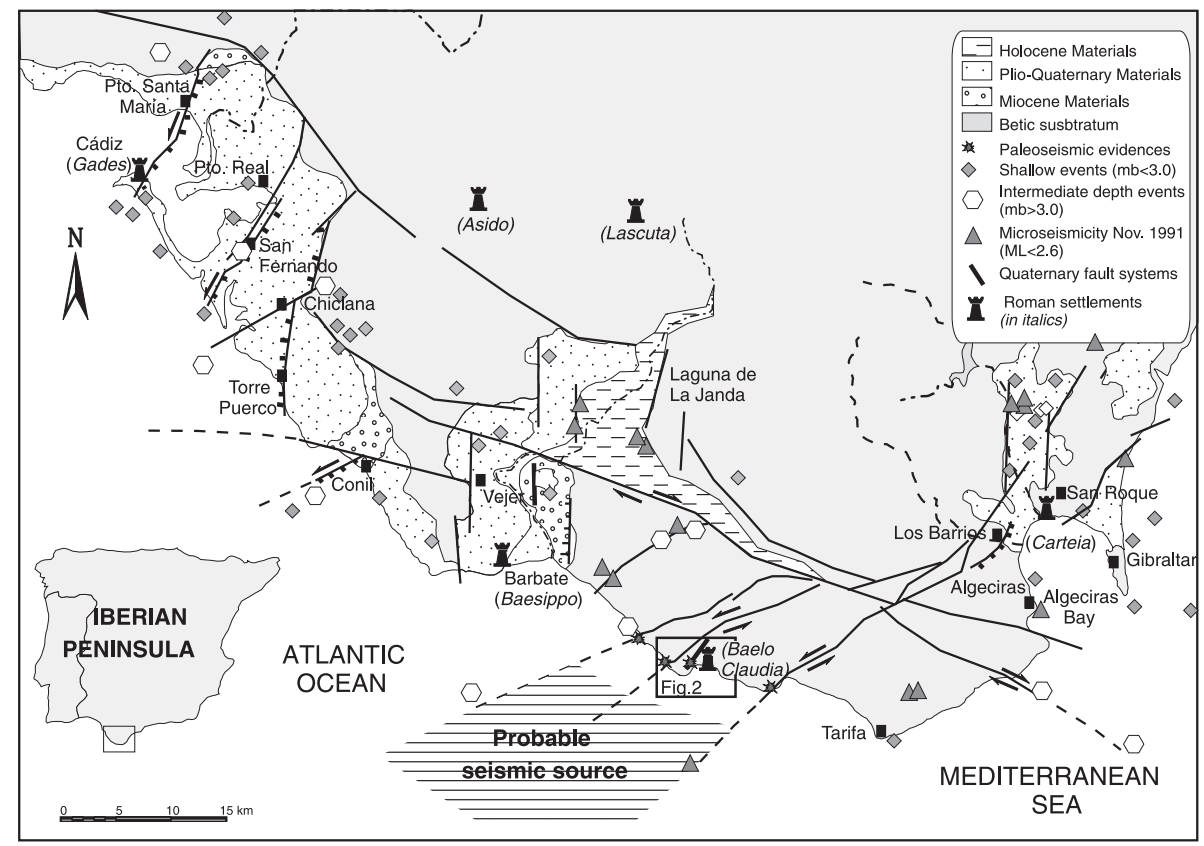

Fig. 1. Neotectonic and seismotectonic framework of the Gibraltar Strait area (south Spain). Seismic data from IGN (1994), Goy et al. (1995), Gracia et al. (1999). Are also included microseismicity data for November 1991 (triangles) survey of Makris and Egloff (1993).

al., 1995). This process of no conservative horizontal strain has been amplified in the Atlantic sector due to the presence of "keuper" and "flysch" plastic materials additionally inducing the occurrence of local dextral slip on the main NE-SW sinistral fault zones. This kinematics behaviour has been reported on faulting structures in Pliocene and Quaternary materials (Benkhelil, 1977; Goy et al., 1995; Gracia et al., 1999). In addition, the more recent deformations recorded on this fault system (some of probable paleoseismic character) are mainly concentrated in the surrounding area of the Bolonia Bay (Fig. 1). Most of them are related to the disruption or dislocation of OIS 5 (Oxygen Isotopic Stage) marine levels along the Cabo de Gracia Fault (CdGF) west of the ancient Baelo (Goy et al., 1995; Zazo et al., 1999), but other are linked to noticeably downthrowning $(>1.2 \mathrm{~km})$ of the PlioQuaternary sequence in the offshore area south of Baelo (Makris and Egloff, 1993).

\subsection{Seismotectonics}

A total amount of only 66 events are catalogued for the period 1750-1993 in the Gibraltar Strait area with a maximum magnitude of $4.7 \mathrm{mb}$ (IGN, 1994), being most of them shallow events $(<10 \mathrm{~km}$ depth) with mean magnitudes down to $3.0 \mathrm{mb}$ (Goy et al., 1995; Liu and Makris, 1995). This seismicity is mainly associated to the activity of the $\mathrm{N}-\mathrm{S}$ to NNE-SSW normal fault systems (Fig. 1) linked to the Mio-Pliocene sedimentary troughs (Goy et al., 1995; Gracia et al., 1999). Microseismicity surveys suggest a regular releasing of seismic energy with 42 shallow events $(\mathrm{ML}<2.6)$ at these troughs during one month of network operation (Makris and Egloff, 1993).

A second population of moderate events ( 3 to 5 $\mathrm{mb}$ ) occurs at intermediate depths of 40-60 km (Fig. 1 ), associated to the offshore prolongation of the main inland NE-SW strike-slip faults (Goy et al., 1995). However, this fault system also displays associated seismicity of 3.4-3.9 mb, but at shallower crustal depths, 20-35 km in the Bolonia Bay (Makris and Egloff, 1993), and 5-10 km in the adjacent Bay of Cadiz (Gracia et al., 1999). One of these faults is the aforementioned CdGF, which shows probable paleoseismic signals of late Pleistocene age at surface (Goy et al., 1994, 1995). A third 
population of deeper events $(60-135 \mathrm{~km})$ is associated to complex eastwards subducted lithospheric slabs beneath the Gibraltar arc (Liu and Makris, 1995).

\section{The Cabo de Gracia Fault Zone}

This constitutes the major fault zone of the Bolonia area, located 2.5-3 km west of Baelo Claudia (Fig. 2) and consisting on a NE-SW sinistral strike-slip fault zone of about 400 to $650 \mathrm{~m}$ wide, and at least $8.65 \mathrm{~km}$ long on the emerged coastal sector. It holds a complex braided pattern comprising ancient reactivated Betic thrust planes and folded mechanical contacts of the Miocene flysch units (i.e. Aljibe Sandstone Fm.) connected by more recent NNE-SSW to N-S fault segments (Fig. 2). The fault zone shapes a linear relief bounded by large NE-SW trending faceted range front-faults (Cabo Gracia coastal range) and SE facing bedrock fault scarps. To the south, close to ancient Baelo, recent deformations of probable paleoseismic origin are recorded along $\mathrm{N} 55-76^{\circ} \mathrm{E}$ reactivated fault segments (Fig. 1). They are related to deformed deep weathered early-middle Pleistocene gravel-sandy marine deposits outcropping in a raised marine platform $(+67 \mathrm{~m})$ at Punta Camarinal (Fig. 2). Two undisturbed aeolian levels bearing Bronze Age $\left(\mathrm{D}_{1}\right)$ and Roman $\left(D_{2}\right)$ remains (Borja et al., 1999), seal the deformed materials indicating that main deformational events occurred before the Bronze Age (Goy et al., 1995).

The NW facing flank of the Cabo de Gracia Fault Zone $(\mathrm{CdGF})$ is defined by a more discrete, continuous, range front fault, which is mainly developed on bedrock materials (Fig. 2). Late Pleistocene marine and aeolian deposits are affected by the littoral termination of this fault zone, giving place to a $9 \mathrm{~m} \mathrm{high}$ spur-ridge structure topped by younger alluvial deposits that display antiform-like deformation. (Goy et al., 1995). In detail this spur ridge, is defined by NNESSW reverse faults with upwards fan-like arrangement and liquefaction phenomena of possible paleoseismic origin (Goy et al., 1994, 1995). The deformed marine-aeolian deposits belong to the Isotopic SubStage (ISS) 5e, meaning that the last probable event recorded on this fault segment should be younger than $128 \mathrm{ka}$ BP (age of the ISS 5e in the Spanish littoral,
Zazo et al., 1999). These paleoseismic evidences indicate that the CdGF is an active structure (Goy et al., 1995; Zazo et al., 1999), and furthermore, this fault is located between the two most active NE-SW strikeslip faults of the Strait area (Fig. 1), linked to seismic activity and identified by seismic profiles (Makris and Egloff, 1993).

\section{The Bolonia Bay}

The Bolonia Bay is carved on intensely deformed flysch units of the Betic Cordillera, consisting in this area on turbiditic Miocene sandstones (Aljibe fm.), and softer plastic marly clays of the Cretaceous-Eocene Bolonia unit (Esteras et al., 1988). The ancient Roman city was founded on the latter (Fig. $2)$. In detail, the present ruins are placed on a gentle colluvial slope developed onto the aforementioned marly clays and in its transition zone to the aeolian and littoral sands of Holocene spit bars (Fig. 3). These littoral landforms are located at +3.5 and $2.5 \mathrm{~m}$ above the present sea level and to the east of the city, the most recent one close an ancient lagoon (Menanteau et al., 1983). Well-log data (S6; Fig. 3) indicate that the dark-silts of the lagoon were buried by a $4 \mathrm{~m}$ thick colluvial sequence of mainly clayey nature. The spit-bar systems and lagoon-clays are dissected by the present drainage network (Fig. 3 ), with development of narrow post-Roman "cut and fill" fluvial terraces. (Gracia and Benavente, 2000).

The Pleistocene sequence of marine deposits in the Bolonia Bay comprise three well developed staircased marine terraces located at $+20-22,+13-14$ and $+7-8 \mathrm{~m}$ above the present sea-level (Fig. 2) today preserved at the adjacent "El Lentiscal" area (Goy et al., 1995). The lower ones, attributed to the ISS $5 \mathrm{c}(+7-8 \mathrm{~m})$ and ISS $5 \mathrm{e}(+13-14 \mathrm{~m})$ by Zazo et al. (1999) are separated by a paleocliff of $8-10 \mathrm{~m}$ high from the higher marine level at $+20-22 \mathrm{~m}$ (Fig. 2). A similar topography develops in the environs of Baelo, with a paleocliff that separates the lower littoral zone of the city from an elevated surface at ca. +20 m (Fig. 3), interpreted as a raised abrasion platform (Menanteau et al., 1983). This staircased topography (Fig. 4), developed in the Bolonia Bay since at least the Late Pleistocene, was gradually 


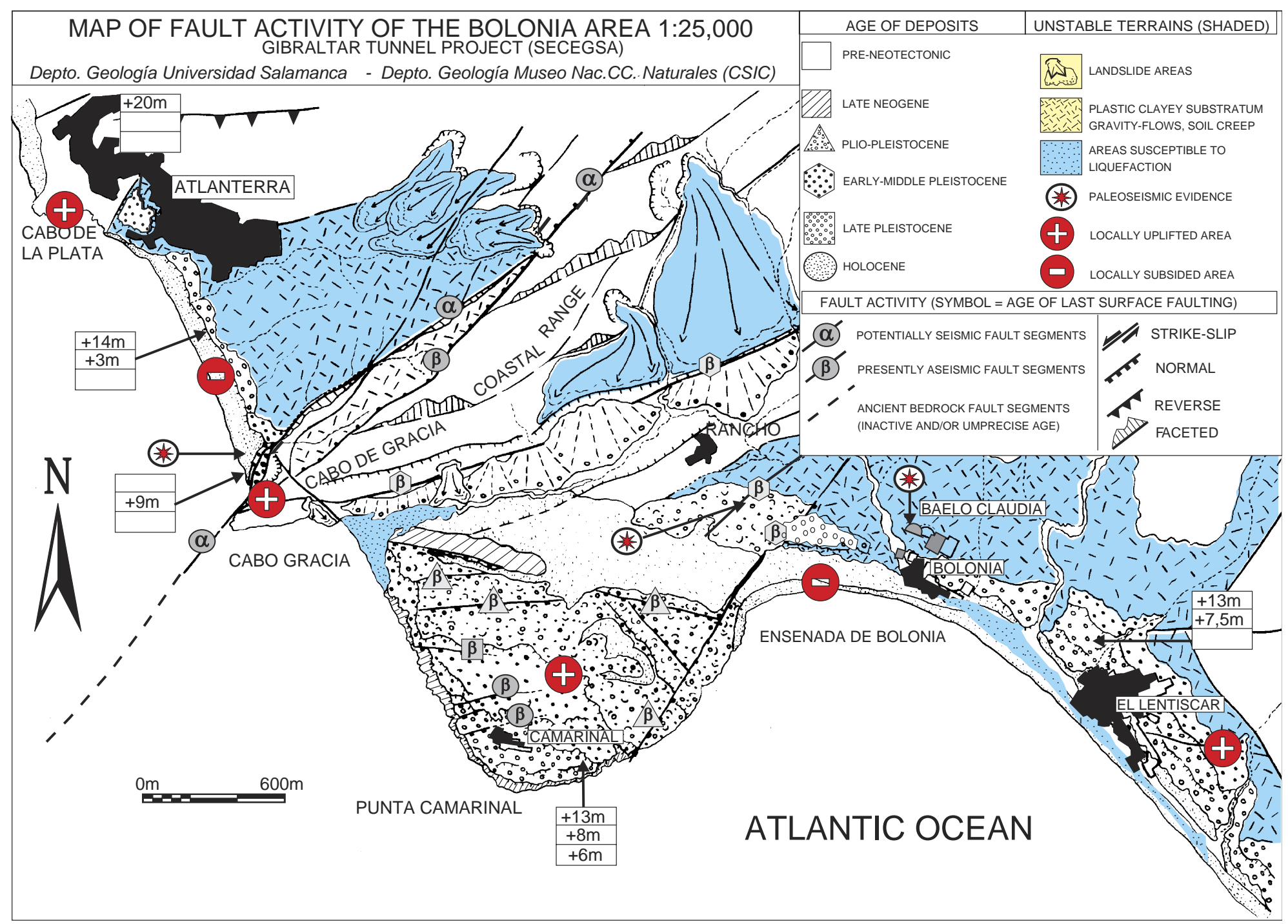

Fig. 2. Neotectonic Map of the Bolonia Area. Squared numerical data corresponds to the present elevation above the sea-level of the ISS 5e, $5 \mathrm{c}$ and $5 \mathrm{a}$ deposits at different coastal segments. 


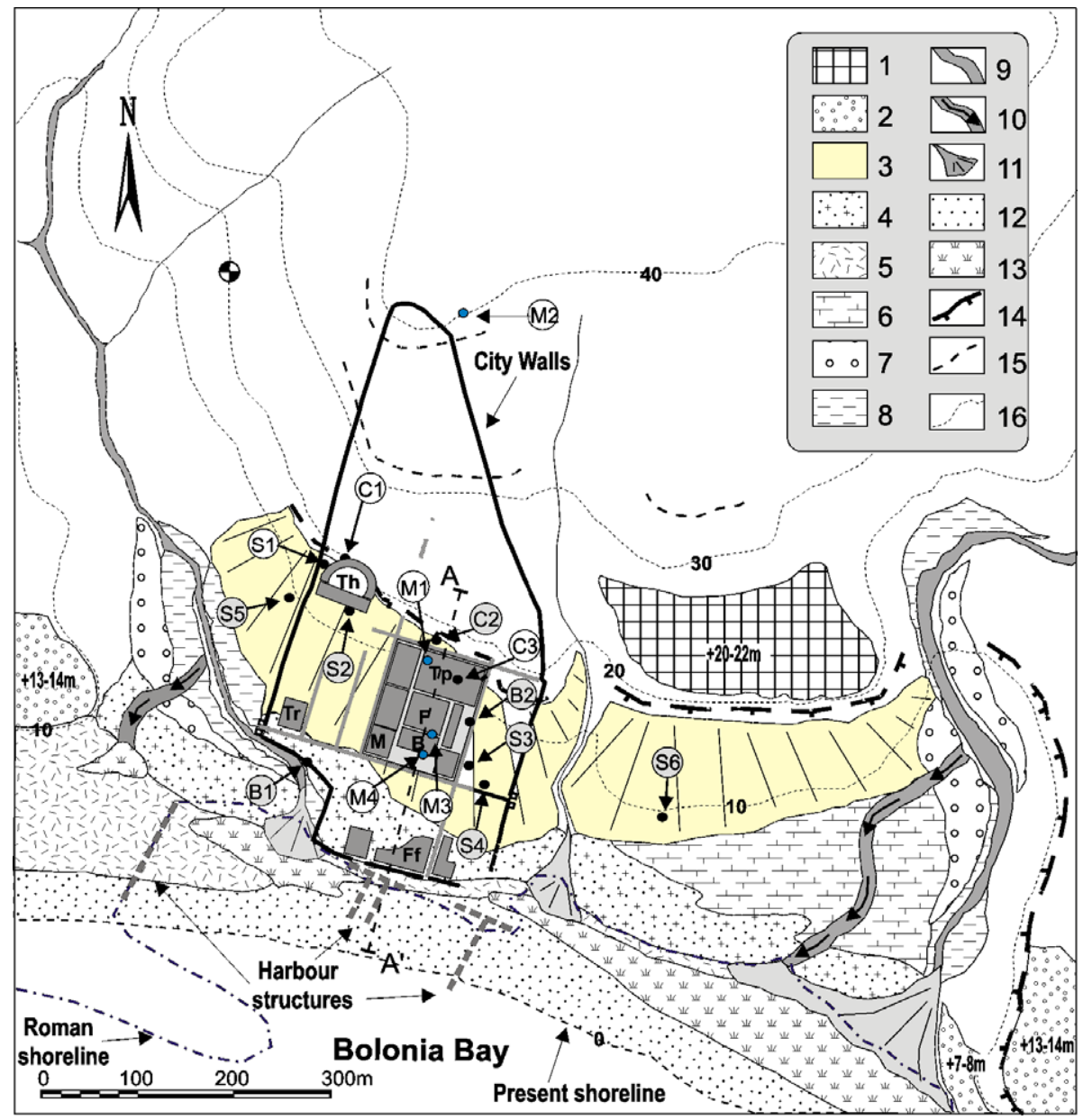

Fig. 3. Geomorphological map of the ancient urban area of Baelo Claudia. (Th) Theatre; (Tp) Temples; (F) Forum; (B) Basilica; (M) Macellum; (Ff) Fish factories; (Tr) Roman Baths. Are also included the locations of the wells (S) developed by Vorsevi (1993, 1995), and the archaeological trenches reported by (M) Menanteau et al. (1983), (C) Borja et al. (1993), and the newly reported in this study (B). Dotted grey lines illustrate the ancient harbour structures and the Roman paleo-shoreline reported by Alonso Villalobos et al. (2003). Legend: (1) Marine abrasion platform; (2) Late Pleistocene Marine terraces; (3) Betic substratum; (4) Holocene spit-bar system including $\mathrm{D}_{1}$ and $\mathrm{D}_{2}$ dune system of south Spain; (5) Recent $\mathrm{D}_{3}$ dune system; (6) Lagoon deposits; (7) Fluvial terraces; (8) Flood plains; (9) Channel beds; (10) Abandoned channels; (11) Terminal river systems; (12) Beach deposits; (13) Marshes; (14) Paleocliff; (15) Bedrock scarps; (16) Contour levels.

occupied during the successive building phases of the roman settlement.

\section{Archeology and history of Baelo Claudia}

Different archeological excavations carried out by the French Institution "La Casa de Velázquez" since 1966, allow a nice insight of the history of an ancient wealthy Roman city in south Spain (Sillières, 1997). The town was settled in the late 2nd Century BC as a strategic site for human and commercial exchange between Europe and Africa during the Roman times. The development of the city followed three well differentiated building periods separated by noticeable discontinuities of the archaeological record interpreted as anomalous episodes of city destruction - or demolition-apparently related to earthquake damage (Menanteau et al., 1983; Sillières, 1995, 1997). History, archaeological recorded events, and dominant surface process in the configuration of the present archaeological site are summarized in Table 1. 


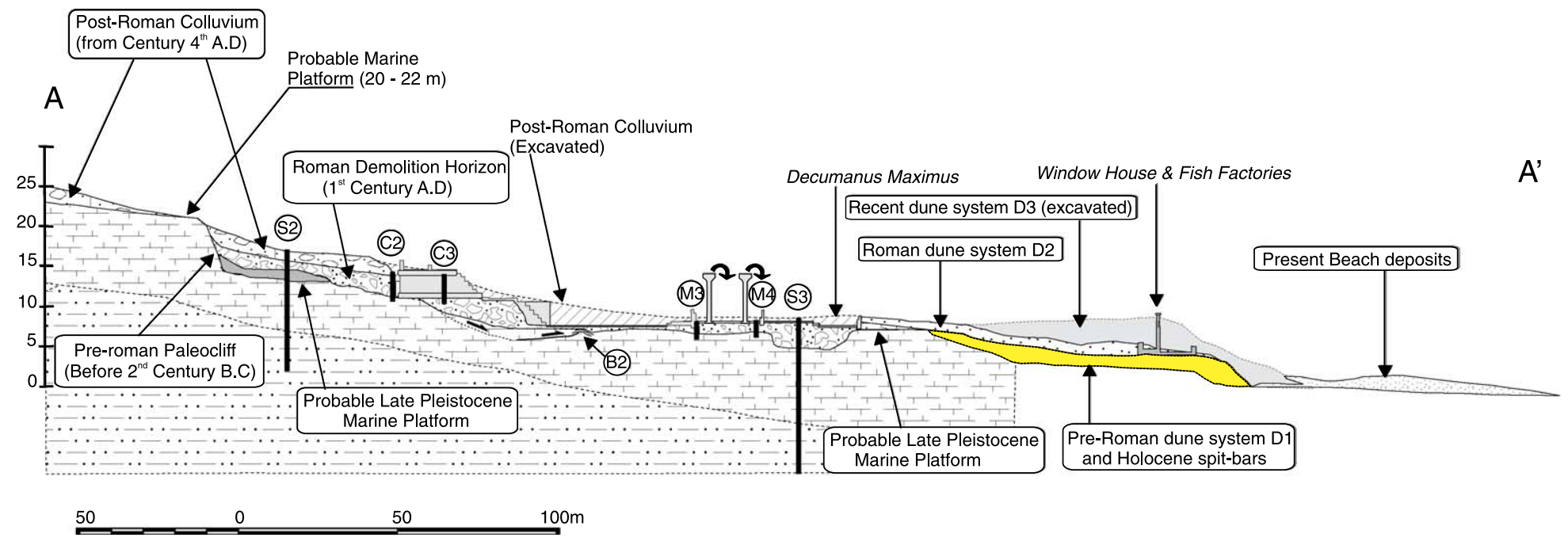

Fig. 4. N-S cross-section of the ancient urban area of Baelo Claudia inferred from well-log and trench data (for location see Fig. 3). Dotted lines represent to the excavated zones. 
Table 1

Periods, events and geological processes related to the configuration of the archaeological site of Baelo Claudia

\begin{tabular}{|c|c|c|c|}
\hline Dates & Historical features & Archeological milestones & Geomorphic and human processes \\
\hline $\begin{array}{l}\text { Before late 2nd } \\
\text { Century BC }\end{array}$ & $\begin{array}{l}\text { No urban settlement in the } \\
\text { zone }\end{array}$ & & $\begin{array}{l}\text { Colluvial slopes partially bury } \\
\text { staircase marine terraces. Dune } \\
\text { system development }\left(D_{1}\right) \text { on the } \\
\text { Holocene spit-bar system }\end{array}$ \\
\hline Late 2nd Century BC & First Roman settlement & $\begin{array}{l}\text { First "fish" factories; increasing } \\
\text { commercial activity with Africa }\end{array}$ & $\begin{array}{l}\text { Scarce human modification (or not } \\
\text { documented). Local incorporation } \\
\text { of archaeological artefacts to } \\
\text { surface formations }\end{array}$ \\
\hline $\begin{array}{l}\text { Late 2nd Century BC to } \\
\text { Middle 1st Century AD }\end{array}$ & $\begin{array}{l}\text { First Building phase (lower } \\
\text { coastal sector). First settlement } \\
\text { becomes Oppidum latinun } \\
\text { (Category of Roman City). } \\
\text { Major urban reforms }\end{array}$ & $\begin{array}{l}\text { Construction of Forum, Ancient } \\
\text { Basilica, Macellum and City Walls } \\
\text { (ca. AD 10-20). Urban orthogonal } \\
\text { pattern }\end{array}$ & $\begin{array}{l}\text { Major landscape reworking. Ground } \\
\text { digging; generation of artificial } \\
\text { talus on colluvial slopes; soil } \\
\text { beheading and alteration of surface } \\
\text { hydrology }\end{array}$ \\
\hline $\begin{array}{l}\text { Late 1st Century AD to } \\
\text { late 4th Century AD }\end{array}$ & $\begin{array}{l}\text { Second building phase. } \\
\text { Maximum extension and } \\
\text { prosperity of the city, which } \\
\text { acquires the imperial label of } \\
\text { Claudia at ca. AD } 48-50\end{array}$ & $\begin{array}{l}\text { Development of the Monumental } \\
\text { zone (Basilica, Temples, Forum, } \\
\text { Curia, and Theatre). Recycling of } \\
\text { previous architectural elements, and } \\
\text { partial use of former foundations }\end{array}$ & $\begin{array}{l}\text { Rebuilding of the city on the " } \\
\text { demolition horizon", artificially } \\
\text { cemented on surface }\end{array}$ \\
\hline $\begin{array}{l}\text { Late 4th Century AD. } \\
\text { (ca. AD 350-395?) } \\
\text { Probable earthquake }\end{array}$ & $\begin{array}{l}\text { Abrupt ruin and urban } \\
\text { depopulation. The damaged } \\
\text { city was never fully abandoned } \\
\text { or rebuilt }\end{array}$ & $\begin{array}{l}\text { Pop-up like deformations in Forum } \\
\text { and Decumanus maximus. Collapse } \\
\text { of Basilica column drums and } \\
\text { Macellum roofs. Westwards tilting } \\
\text { of most walls and City Walls }\end{array}$ & $\begin{array}{l}\text { Roman and post-roman colluvial } \\
\text { formations bury the damaged } \\
\text { remains of the city. Coastward } \\
\text { shifting to Dune system } \mathrm{D}_{2}\end{array}$ \\
\hline $\begin{array}{l}\text { Late 4th Century AD to } \\
\text { ca } 7 \text { th Century AD }\end{array}$ & $\begin{array}{l}\text { Third building phase. Small } \\
\text { Paleo-Christian settlement on } \\
\text { former monumental zone, with } \\
\text { different urban pattern }\end{array}$ & $\begin{array}{l}\text { Definitive abandonment before the } \\
\text { AD } 711 \text { Arab conquest of the } \\
\text { Iberian Peninsula }\end{array}$ & $\begin{array}{l}\text { Colluvial burying of the destroyed } \\
\text { roman city. Soil swelling and slope } \\
\text { creeping }\end{array}$ \\
\hline
\end{tabular}

The intervening destructive episodes can be relatively dated on the basis of archeological evidence. The first period of City destruction can be dated between $\mathrm{AD} 40$ and 60 by the presence of pottery remains beneath collapsed walls, close to the repaired sector of the damaged City Wall (Sillières, 1997). In addition, this period is post-dated by the occurrence of an anomalous level of demolition related to ground leveling works on the whole lower sector of the city (Macellum, Basilica, Forum) and reparation works in different severely damaged sectors of the City Wall during AD 30-50 (Sillières, 1995, 1997).

The eventual episode of abrupt ruin of the city has been bracketed between the late 3rd to late 4th Century AD. Nevertheless, numismatic evidence reveals the occurrence of a significant city-decay period between AD 364 and 395 coeval with severe collapse of buildings, which culminates with the total lack of coins (roman or other) from AD 395 (Menanteau et al., 1983; Bost et al., 1987). This feature indicates a nearly total failure of the commercial activity in the City, although a reduced activity is recorded during following 5th and 6th centuries $\mathrm{AD}$ when commercial exchange is demonstrated by the presence of African and Phoenician pottery (Sillières, 1997). On the other hand, the period of main destruction of the City Walls and Macellum (Market) can be bracketed between AD 350 and 370 from pottery evidences (Didierjean et al., 1978). Menanteau et al. (1983) proposed the time interval AD 350-395 as the bracketed age for the probable causative earthquake. 


\section{Urban geology of Baelo Claudia}

A complex Roman and post-Roman formation of polygenic origin covers the ancient urban area (Borja et al., 1993) mainly in the lower sector of the city, at the base of the aforementioned paleocliff (Fig. 3). This lower sector has a near horizontal slope, constituting a plane-surface at $+8-7 \mathrm{~m}$ above the present sea level, and comprises the main Monumental zone (Forum, Capitol, Basilica, Macellum, etc.) limited to the south by the Decumanus maximus (Fig. 3). From the Decumanus maximus to the shore, the rest of the city (private houses and fish-Garum-factories) lays on poorly consolidated aeolian sands. The older deposits correspond to the first Holocene aeolian system widely developed in the south Spanish littoral between $2700 \mathrm{BP}$ and the early 2nd century BC (pre-Roman $\mathrm{D}_{1}$ System of Borja et al., 1999). Recent submarine and geoelectrical surveys (Alonso Villalobos et al., 2003) carried out in the present bay and beach testify the ancient roman paleo-shoreline as well as different harbour structures (boat ramps) built on beach deposits associated to the Roman dune System $\left(\mathrm{D}_{2}\right)$ of Borja et al. (1999).

The overall stratigraphy of the urban area has been established by means of different sets of well-log data (Vorsevi, 1993, 1995) and archaeological trenches studied by Menanteau et al. (1983) and Borja et al. (1993), some of them revised, and re-interpreted, for this study. In detail two main units can be differentiated: (a) the plastic clayey substratum where most of the urban area is founded, and (b) an upper complexpoligenic formation that embed and bury the archaeological remains. Main characteristics and geotechnical properties of the different units are summarized in Table 2 and their spatial relationships and geometry sketched in Fig. 3.

\subsection{The plastic clayey substratum}

The buildings were directly founded on the clayey substratum only in the upper sector of the city (i.e. Theatre sector) (Fig. 3). The occurrence of weakly developed vertic soils is common at outcropping sites M1 and C1 (Fig. 3) (Borja et al., 1993). When buried (M2, C2; Fig. 3) these soils are beheaded (by human dig-works) and B-horizons are absent, and at the southern part of the Forum (M2; Fig. 3) there upper part is affected by pseudo-convolutes related to solifluction-like processes (Menanteau et al., 1983).

In all the studied logs, the upper $0.2-0.4 \mathrm{~m}$ of this formation appears highly fissured with reworked detritical materials (beheaded soils and/or weathering horizons). The plastic substratum always appears beneath this weathered horizon leading to the accumulation of ground water at their interface. This feature gives place to the occurrence of a highly discontinuous and partitioned phreatic level, conditioned by the thickness of the complex-antrophic formation, the previous levelled topography, and the remains of wall-foundations (Borja et al., 1993). In consequence those zones artificially levelled (e.g., Monumental zone) favour the accumulation of groundwater, enhancing the natural unstable behaviour of these materials, that can be catalogued as expansive (CH-CL) soils of the Unified Soil Classification System (USCS: Table 2).

\subsection{The Upper complex polygenic unit}

This formation is constituted by poorly consolidated rubbish and debris embedded in a clayey matrix with many archaeological remains (stone blocks, ashlars, pottery, etc.) of 2.3-4.4 m thick, resting on top of the plastic clayey marls of the Bolonia Unit (Borja et al., 1993). In detail it comprises different levels of different origin (Table 2 and Fig. 4).

Pre-Roman and post-Roman formations are constituted by well developed colluvial wedges that grade towards de coastal sector (i.e. from the Decumanus maximus) into the $\mathrm{D}_{1}$ and $\mathrm{D}_{2}$ Dune systems, previously defined for southern Spain (Borja et al., 1999). From the palaeoseismic point of view the most interesting formation is the already mentioned "Demolition Horizon", which appears either between these two colluvial formations at the base of the ancient paleocliff (Sector of the Temples) and/or directly mantling the plastic clayey substratum over the rest of the lower sector of the City (Fig. 3).

\subsubsection{Pre-Roman formations}

The logs located at the base of the paleocliff (S2 to S5: Fig. 3) record a pre-Roman colluvial level at the top of the weathered plastic substratum (Fig. 4) with 
Table 2

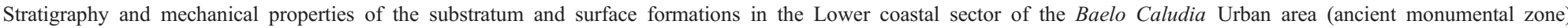

\begin{tabular}{|c|c|c|c|c|c|c|}
\hline Unit & $\begin{array}{l}\text { Depth } \\
\text { (thickness) }\end{array}$ & Lithology & Age & Mechanical properties & & \\
\hline $\begin{array}{l}\text { Post-Roman colluvium. } \\
\text { Coastward grading } \\
\text { to } \mathrm{D}_{2} \text { dune system }\end{array}$ & $(0.8-1.0 \mathrm{~m})$ & $\begin{array}{l}\text { Colluvial deposits with } \\
\text { archaeological artefacts, bones, } \\
\text { carbons, etc. }\end{array}$ & $<4$ th Century AD & $\begin{array}{l}\text { Poorly cemented-no } \\
\text { data-no relevance for } \\
\text { this study }\end{array}$ & & $\begin{array}{l}\text { Upper complex } \\
\text { polygenic unit }\end{array}$ \\
\hline $\begin{array}{l}\text { Roman demolition } \\
\text { horizon }\end{array}$ & $(1.5-2.3 \mathrm{~m})$ & $\begin{array}{l}\text { Artificial filling. Stone blocks, } \\
\text { bricks, and boulders of clays } \\
\text { pasted in a clayey matrix }\end{array}$ & ca. $\mathrm{AD} 40-60$ & $\begin{array}{l}\text { C3 Soil (NCS-94), UCS }<2 \\
\mathrm{~kg} / \mathrm{cm}^{2} \text {, SPT }(N=14 \text { to } 20) \text {, } \\
\text { top consolidated (Roman } \\
\text { moles): SPT peaks of } N>90 \text { in } \\
\text { the upper } 0.1 \mathrm{~m}\end{array}$ & $\begin{array}{l}\text { Damaged buildings } \\
\text { founded partially or } \\
\text { totally in these } \\
\text { materials }\end{array}$ & \\
\hline $\begin{array}{l}\text { Pre-roman colluvium. } \\
\text { Coastward grading } \\
\text { to } D_{1} \text { Dune system }\end{array}$ & $(0.9-2.1 \mathrm{~m})$ & $\begin{array}{l}\text { Subangular gravels and } \\
\text { boulders with clayey-sandy } \\
\text { matrix. Capped in S2 by } 0.2 \mathrm{~m} \\
\text { thick littoral deposits at }+13 \mathrm{~m} \\
\text { above the present sea-level }\end{array}$ & $\begin{array}{l}\text { Holocene to } \\
\text { Upper Pleistocene }\end{array}$ & $\begin{array}{l}\text { Poorly cemented-no } \\
\text { data-(only relevant at the toe } \\
\text { of the paleocliff: area of the } \\
\text { temples, north of the Forum) }\end{array}$ & & \\
\hline Upper plastic clays & $\begin{array}{l}2.3-4.4 \mathrm{~m} \\
(6 \mathrm{~m})\end{array}$ & $\begin{array}{l}\text { Variegated plastic clays and } \\
\text { marls, with limited soil } \\
\text { development at top. This } \\
\text { constitutes the natural } \\
\text { foundations of the different } \\
\text { Roman settlements covering } \\
\text { the whole lower sector }\end{array}$ & Eocene Bolonia Fm & $\begin{array}{l}\text { CH-CL soil (USCS) expansive } \\
\text { soils, C3 soil (NSC-94). UCS: } \\
3.82-2.45 \mathrm{~kg} / \mathrm{cm}^{2} \text {, liquid limit: } \\
50-61 \text {, plastic limit: } 22-27 \text {, } \\
\text { swelling potential: } 0.6-1.70 \\
\mathrm{~kg} / \mathrm{cm}^{2} \text {, locally up to } 2 \mathrm{~kg} / \mathrm{cm}^{2}\end{array}$ & & $\begin{array}{l}\text { Plastic } \\
\text { substratum }\end{array}$ \\
\hline Basal clays & $\begin{array}{l}8.0-9.1 \mathrm{~m} \\
(6-7 \mathrm{~m})\end{array}$ & $\begin{array}{l}\text { Red clays with interbedded } \\
\text { sandstones }\end{array}$ & Eocene Betic Flysch & $\begin{array}{l}\text { CH Soil (USCS)/C2 soil } \\
\text { (NSC-94), liquid limit: 49-61, } \\
\text { plastic limit: } 28-34\end{array}$ & & \\
\hline
\end{tabular}

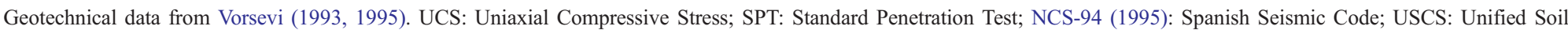
Classification System. 
thickness ranging from 0.9 (S2) to $2.1 \mathrm{~m}$ (S5), and thinning towards the coast (Fig. 3), where the most recent Dune systems $\left(\mathrm{D}_{1}\right.$ of Borja et al., 1999) are dominant. These colluvial deposits are constituted by rounded and subangular gravels and boulders embedded in a clayey-sandy matrix, interpreted as colluvial toe-cliff deposits. (Fig. 4).

\subsubsection{Roman formations: the demolition horizon}

This unit constitutes the best developed, and thicker, geo-archaeological horizon of the city and in all cases rest over the clayey substratum and/or preRoman formations (base of the paleocliff: Fig. 3). This horizon is constituted by artificial fillings for ground levelling (Sillières, 1997), which embed the remains and foundations of the first city building period (Table 1). The artificial filling is in general of silty-clayey nature, but large stone-blocks, bricks and boulders of the removed soft substratum are also incorporated. Artificially compacted mortar of ca. $0.1 \mathrm{~m}$ thick (S2), constituted by cemented sands and consolidated red clays, cap this anomalous "demolition" archaeological horizon in different sectors of the city (Sillières, 1997; Hoyos et al., 1999). The poor geotechnical properties of this Roman artificial filling (Table 2), and its significant thickness $(1.5-2.5 \mathrm{~m})$ in some sectors assisted the eventual period of abrupt ruin and destruction of the city.

\subsubsection{The "post-Roman" formations}

These formations are mainly constituted by a "post-Roman" colluvium developed from the late 4th Century AD, after the abrupt ruin of the city. This has a mainly clayey nature and includes many archaeological artefacts, bones and carbons, showing a very weak soil development on top. This level buried the damaged architectural remains of the city, although it has been removed in the excavated sectors (Fig. 3). This archaeological level post-dates the eventual desertion of the city and main characteristics are listed in Tables 1 and 2 .

\section{Disturbed architectural relics at Baelo Claudia}

Main evidences of city destruction correspond to the second event (AD 350-395). The City Walls are severely tilted towards the west in several sectors of the ancient perimeter of the city (Menanteau et al., 1983). In the Basilica all the columns collapsed, most of them towards the SE, with all the column-drums in domino-style connection. Block impacts in the ancient floor of this building are numerous (Sillières, 1997) and there is no debris-layer between the columns drums and the ancient floor indicating the sharp character of the collapse event. In the Capitolio, Isis Temple and the Curia, some of the walls also underwent a directed westward collapse without relevant dislocations (Sillières, 1997). Numerous house-walls, remains of columns and arch bases are also substantially tilted or toppled to the west (Menanteau et al., 1983; Sillières, 1995). However, the most impressive evidence is the upthrusting and folding of wall-foundations in the NW sector of the ancient Forum, observed during the excavations of 1991. Most of these evidences were prematurely restored, removed, or buried, during the successive archeological excavations and/or during the more recent tourist implementation of the ruins. Nowadays, the only preserved evidence of this destruction episode is the severely disturbed pavement (pop-up like arrays) at the ancient Forum and Decumanus maximus (main street) as reported by Goy et al. (1994).

\subsection{Pop-up like arrays in the Forum}

The main disturbed relics (presently preserved) occur at the ancient Forum, where flagstone couplets of the Roman pavement are deformed showing popup like alignments. They are arranged in seven different lineaments crossing the entire pavement zone with consistent $\mathrm{N} 110^{\circ} \mathrm{E}$ orientations (Fig. 5). These lineaments show a spacing ranging from 7.35 to 6.25 $\mathrm{m}$, but in the southern sector there are some less developed intermediate lineaments with spacing of 2.5-3.7 m. In most of the cases, the flagstone couplets spur against each other, or even are partially upthrusted, displaying maximum vertical displacements of 4-6 cm and overlapped sections of 3-2 $\mathrm{cm}$ (Fig. 6A). Only in two isolated cases pop-up like deformation is produced by rupture of individual flagstones. In any case, pop-up trends are strongly conditioned by the orthogonal disposition of the Forum pavement, and possibly by other intervening ground destabilization process (as we will see below). 


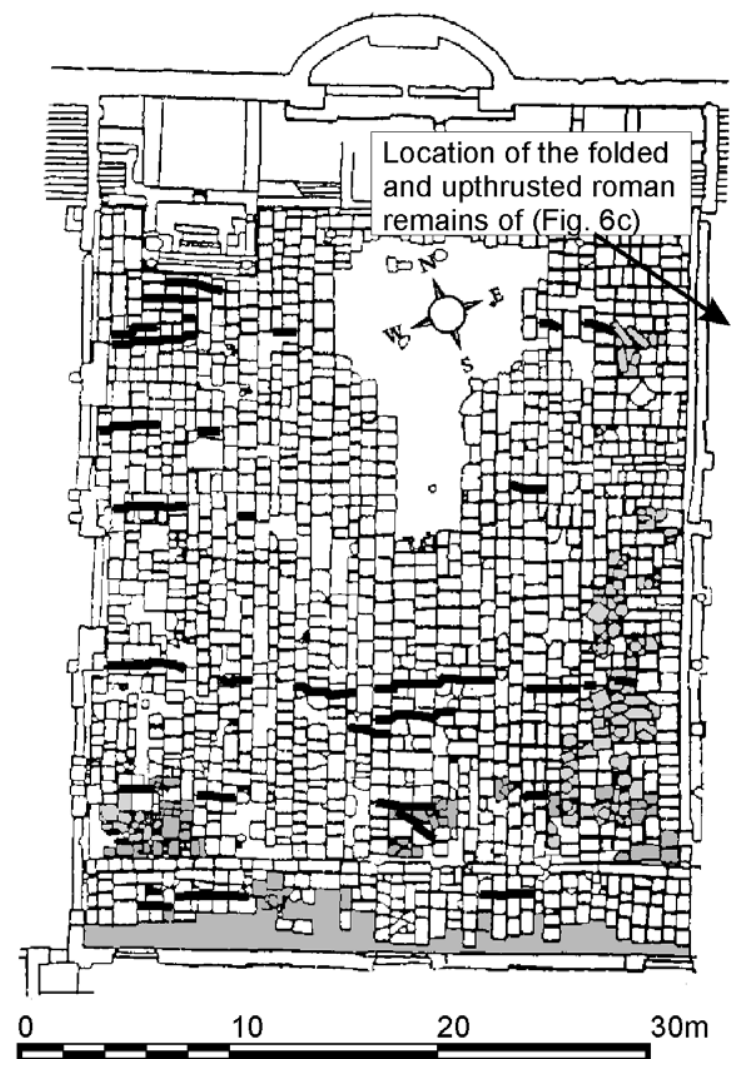

Fig. 5. Arrangement of the pop-up like lineaments (bold lines) and disorganised pavement sectors (grey) observed at the forum of Baelo Claudia.

\subsection{Pop-up like arrays in the Decumanus maximus}

In this case irregular shaped (and larger) polygonal flagstones constitute the pavement. They are highly disturbed showing pop-up like deformations mainly defined by the connection of ruptures on individual flagstones. They are arranged following a main $\mathrm{N} 130-125^{\circ} \mathrm{E}$ orientation and a secondary $\mathrm{N} 50-60^{\circ} \mathrm{E}$ one. Vertical displacements close to $30 \mathrm{~cm}$ and intraflagstone upthrusting, are common. At this site, popup like arrays are not apparently conditioned by any architectural pattern but their lineaments display a clear arched geometry, curved towards the SW. Finally, like in the Forum, the ancient pavement in the zone close to the Basilica, is highly disorganized and deformed, showing a randomly oriented "scour and ridge" micro-topography. Flagstones are tilted a maximum of $25^{\circ}$ towards SW and SE, vertical dis- placements are close to 50 and $2-4 \mathrm{~cm}$ wide open fractures are observed. This deformational assemblage could be interpreted as a consequence of the southerly collapse of the Basilica columns (Fig. 6B). In the rest of the city, that is still partially buried, only isolated deformations can be observed. They are related to the occurrence of individual pop-up like arrays at the Theater scenario, with similar orientations than those observed at the Forum.

\subsection{Folding and upthrusting of house walls, pavements and foundations}

The most impressive deformation of the city (nowadays buried) is the occurrence of a ENE-WSW trending asymmetric fold affecting the western $\mathrm{N}-\mathrm{S}$ oriented walls of the Forum. The theoretical prolongation of the fold axis roughly coincides with the first pop-up like arrangement at the Forum. This larger deformation can be described as an upthrust (or incipient reverse fault scarp facing to the SW) affecting the foundations of the first Roman settlement (>AD 4060 ) and the plastic clayey substratum (Fig. 6C). The available data do not allow to characterize this structure as a true ground rupture evidence (i.e. faulting), but may be generated by a local landslide of the substratum detached from the base of the ancient paleocliff(Fig. 4).In detail this structure is a composite one. The basal part is characterized by asymmetric folding affecting the ancient basement and pavement of the first Roman settlement ( $<$ AD $40-60$ ), founded on the plastic substratum, with a maximum vertical dislocation (i.e. "fault throw") of about $1.2 \mathrm{~m}$ (Fig. 6C). The upper part is an upthrusted house-wall $(0.8 \mathrm{~m}$ high) with a minimum estimated offset of $0.35-0.30$ $\mathrm{m}$, but subsequently leveled by the "demolition horizon" (AD 40-60). Finally the pavement placed on the leveled ground ( $>$ AD $40-60$ ) is fairly dislocated $(0.20-0.15 \mathrm{~m})$ in a pop-up like style (Fig. 6C).

In fact, most of the described deformations affect the remains of first building period latter leveled with the "demolition horizon". The different styles of deformation recorded by this structure are mainly consequence of the "differential-response" of the architectural elements located beneath (folding) or above (upthrusting) the ancient ground surface. The leveled ground surface was disrupted again (in a weaker way) during the second episode of city 

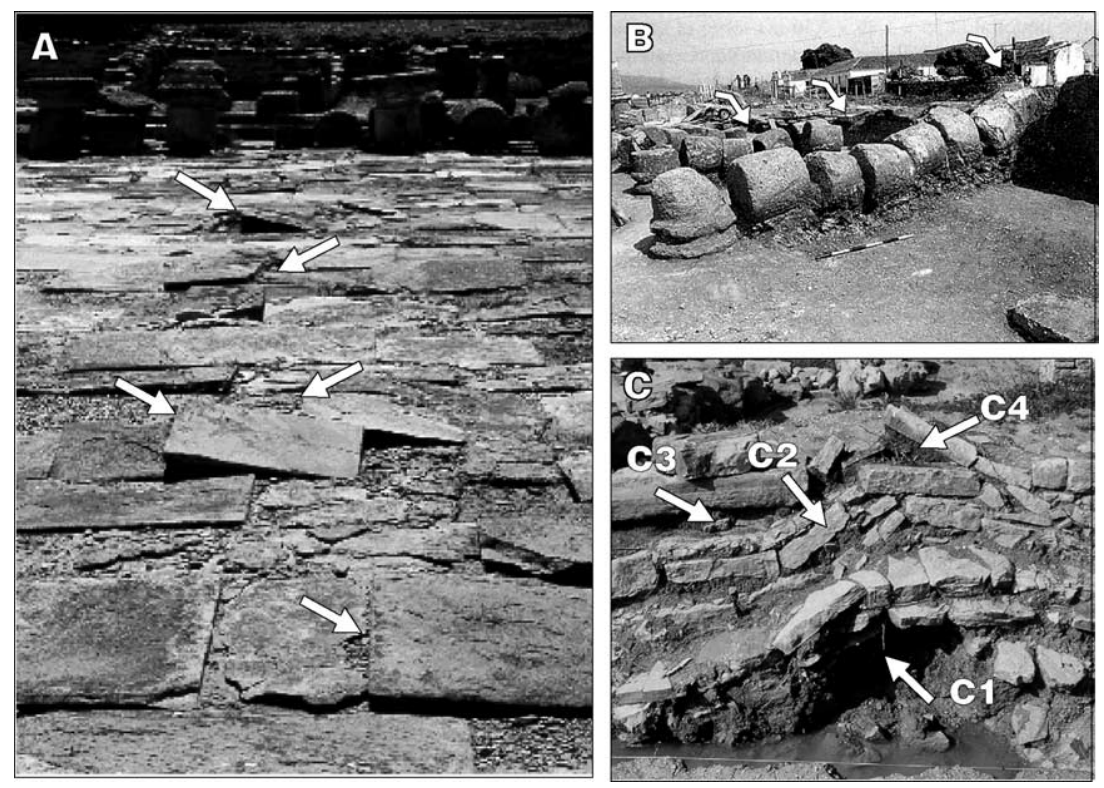

Fig. 6. (A) Pop-up like deformations of Flagstones in the Forum of Baelo Claudia. Arrows indicate overthrusted slabs. (B) Southerly collapsed columns at the Basilica (after Sillières, 1997); (C) Landslide-induced folded and upthrusted remains at the NW corner of the Forum. C1: Folded roman pavement AD 40-60; C2: Faulted house ashlars AD 40-60; C3: Demolition horizon AD 40-60; C4: Upthrusted house-basement AD 350-395.

destruction by reactivation of the structure. In this sense, the pop-up like arrays recorded at the Forum can be reasonably interpreted as the eastwards propagation of these reactivated structures comprised within the "demolition horizon". Supporting this interpretation, the house walls of the western side of the Forum displayed an E-W bending (zig-zag waving) from north (Temples) to south (Basilica). Unfortunately this sector was also restored in the early 1990 s.

Therefore these deformations illustrate one of processes (i.e. landsliding) responsible for the first destruction of the city (AD 40-60), but apparently reactivated during the second one (AD 350-395). Nevertheless, the classification of this ground rupture evidence as a coseismic surface faulting is not possible on the basis of the available data.

\section{Discussion}

\subsection{The earthquake problem}

The main period of city destruction has been bracketed between AD 350 and 395 on the basis of numismatic and pottery evidences. In any case an additional problem to assessing the coseismic nature of the reported disturbances is that no earthquake is listed in the Spanish catalogue during such period. Consequently, Menanteau et al. (1983) linked the eventual destruction of the city to relatively far-strong earthquakes, such as those occurred in the San Vicente Cape (south Portugal: AD 382) or in the Mediterranean (AD 365) as reported in the first catalogues for Spain and north Africa (Galbis, 1932; Stahl, 1971; Hatzfeld, 1976). The interpretation of Menanteau et al. (1983) was largely influenced from the fact that during the destructive 1755 Lisbon Earthquake-Tsunami, the Gibraltar Strait area suffered intensities of VI-VII MSK (Galbis, 1940; Martínez Solares et al., 1979), although isoseismal maps based on damage in low-rise buildings (high-frequency structures) designated lower intensities of V-VI MSK for the studied zone (Martínez Solares et al., 1979). These values of intensity are however insufficient to explain the extensive destruction of the city by such a kind of strong Atlantic earthquakes.

Regarding to the Mediterranean case, the ancient chronicles (compiled in Galbis, 1932) described the 
event as felt along the entire south Iberian littoral, but with major damage caused in the adjacent littoral of Malaga, probably by tsunami waves. This situation led to the identification of this event with the AD 365 Crete earthquake-tsunami in more recent catalogues. However, Stiros (2001) showed that the present available data do not provide support to assign seismic damage evidence beyond Libya-Sicily (i.e Tunis or Algeria) to the Crete event, and the reported damage in these areas may be simply related to other local earthquakes, occurred during the socalled "Early Bizantine Tectonic Paroxysm" in the Mediterranean area (4th-6th centuries AD; Stiros, 2001).

The AD 365 event listed by Galbis (1932) could therefore occur in Spanish Mediterranean littoral as initially considered by Menanteau et al. (1983), but any data let to verify related damage south of the city of Malaga (Fig. 1). From the newly collected data, a reasonable "local" interpretation can be outlined. Nearby NE-SW trending strike-slip faults display signs of recent activity and they are presently related

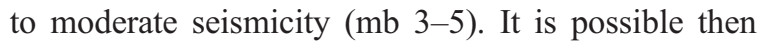
that moderate(s) near-quake(s), not especially noticeable in other zones (mainly unpopulated for that time; Fig. 1) could cause the observed deformations. Nevertheless, it is necessary to assume that: (a) seismic shaking was amplified at the Baelo urban area by the unstable conditions of the ground; and (b) coeval secondary ground failure processes (e.g. landslides) increased the damage.

Recent cases illustrates that modest pop-up like structures can be developed by close moderate earthquakes, as is the case of the 1995 Ms 6.1-5.6 Egion Earthquake in the Gulf of Corinth (Mariolakos et al., 1998). These authors reported the development of pop-up like structures in floor-stone couplets on a $0.3 \mathrm{~m}$ thick cemented mole founded on loose saturated-coastal deposits, at Eratini, $10 \mathrm{~km}$ away from the epicenter. In our case, the Roman pavement only has a thin $(0.1 \mathrm{~m})$ mortar founded on a highly unstable ground (Hoyos et al., 1999) and the suspect faults are located less than $3 \mathrm{~km}$ away (i.e. CdGF). This means that a moderate earthquake (ca. $5 \mathrm{mb}$ ), with epicenter close to Baelo Claudia might promote the set of described pop-up like arrays, and severe building damage in the lower sector of the city. In addition, the folded foundations within the demoli- tion horizon indicate that limited landsliding at the ancient toe-cliff zone participated in both episodes of city destruction enhancing the ground behaviour in building damage.

The reported disturbances fall within the categories of secondary (AD 40-60) and ground shaking (AD 350-395) archeoseismological evidences listed by Hancock and Altunel (1997), therefore their characterization as true coseismic evidences is still problematic. Other episodic high-energy natural events like, tsunamis, typhoons, or large mass-wasting events, could also account for the observed archaeological evidences. Nevertheless, the available historic and geological data do not support the occurrence of the aforementioned phenomena, during the destruction periods. Conversely, the archaeological record of Baelo Claudia displays relevant similarities with many other ancient cities destroyed by earthquakes during the Roman period throughout the Mediterranean. Among others it is relevant to the occurrence of re-building phases, with the incorporation of many architectural elements of previous building phases, such as the case of the Ancient Kisamos in Crete (Stiros and Papageourgiu, 2001), or the occurrence of destruction horizons as is the case of the aforementioned Kisamos or Cnydus in Turkey (Altunel et al., 2003). In addition, the occurrence of widespread pop-up like disturbance of pavements is documented in recent (Mariolakos et al., 1998), but also in ancient earthquakes in the Middle East and Greece (Karcz and Kafri, 1978; Stiros, 1996). All these common features of Baelo Claudia with other earthquake-damaged cities, together with the reported assemblage of deformations and ground failure processes, make the seismic hypothesis as the chosen choice to explain the anomalous development of the city highlighted by the archaeologists (Bost et al., 1987; Bourgeois et al., 1991; Sillières, 1995, 1997).

\subsection{Expected ground-site response from local seismicity}

The geology and geomorphological data indicate that episodes of city destruction could be favoured and/or promoted by the striking ground instability of the ancient urban area. Some studies (Borja et al., 1993) related pavement disruptions to volumetric 
changes of the expansive plastic substratum (see Table 2). Moreover, main deformations are always linked to those zones founded on the poorly compacted "demolition" horizon at the lower sector of the city (Forum, Basilica and Decumanus maximus). In contrast, those buildings totally or partially founded on the plastic clayey substratum (Theatre, Temples, upper sector of the city) or in the coastal aeolian materials (Fish factories) do not record relevant deformations. This evidence suggests that the natural ground instability promoted by the volumetric changes of the plastic substratum is not the main triggering-factor of the observed deformations. However, these plastic materials could however play a significant role in the alteration of the Roman settlement at different times and with different styles: (a) the amplification of ground motion, and even partial flow slides and/or solifluction, by the occurrence of seismic shaking; and (b) the magnification of the observed deformations during the eventual burying process of the damaged city.

The Spanish Seismic Code (NCS-94, 1995) considers that local seismicity can promote average horizontal acceleration values of $0.07 \mathrm{~g}\left(\mathrm{a}_{\mathrm{b}}\right)$ in the zone. On the basis of the geotechnical data addressed in Table 2 the ground of the ancient urban area can be classified as weak cohesive soils (Type-II Soils NCS94). Considering the "Soil Coefficient $(C=1.4)$ " assigned in the NCS-94 for this kind of soft ground, approaches for different risk scenarios indicates expected ground pseudo-accelerations $\left(S_{\mathrm{am}}\right)$ ranging between 0.15 and $0.20 \mathrm{~g}$. In addition, the associated ground-response elastic spectra (also standardized in the NCS-94) indicate that these acceleration values are mainly developed for vibrations periods between 0.20 to $0.59 \mathrm{~s}$, in other words especially hazardous for low buildings in areas close to the suspected epicenter (Coburn and Spence, 1992). On the contrary, if far seismicity is taken into account, the standardized values considered in the NCS-94 indicate similar $S_{\text {am }}$ values (0.16-0.21 g) but migrated to longer vibration periods of 0.28 to $0.77 \mathrm{~s}$. These last obtained values are more dangerous to low frequency structures (high buildings) located relatively far away from the suspected epicenter (Coburn and Spence, 1992).

In consequence, the application of the NCS-94 to characterize the probable ground-site response of the lower sector of the Baelo urban area from an eventual seismic shaking indicates that:

a) The obtained values are sufficient to promote the reported processes of ground destabilization and building damage. For example, unreinforced adobe buildings can even collapse under horizontal accelerations as small as $0.1 \mathrm{~g}$ (Bolt, 1993).

b) Local seismicity can explain better the reported damage in low-rise buildings than far away strong events.

c) The obtained Sam values $0.15-0.20 \mathrm{~g}$ are usually associated to earthquake intensities of VII MSK (Bolt, 1993). In the same way, local landslides have been reported to occur from intensities of $\mathrm{V}-$ VI, but found to be common for VI-VII (Serva, 1994; Esposito et al., 1997). Finally recent moderate earthquakes (Ms 5-6) in south Italy (Michetti et al., 2000) and Greece (Mariolakos et al., 1998) indicate that similar pop-up like features and discrete landslides can be produced by intensities of VI-VII MSK. However, the level of destruction recorded in the architectural relicts of Baelo Claudia let to infer a peak intensity of IX-X MSK at least in the lower coastal sector of the city. This fact can only be explained by a local over-amplification induced by the softer artificial filling of the horizon of demolition, thicker at this zone. Whatever the case the used seismic code (NCS-94, 1995) does not take into account any specific amplification factor and therefore the estimated values of ground acceleration are undersized.

\subsection{Ground motion and probable location of the seismic source}

The orientation of the pop-up like arrays indicates that ground shortening took place in a main NE-SW orientation. These arrays are refracted in the Forum due to the orthogonal pattern of the ancient Roman pavement and to the reactivation of previous landslide structures. The NE-SW orientation is parallel to the main strike-slip faults of the zone (Fig. 1), and in particular consistent with the overall sinistral behaviour of the CdGF. The NE bended geometry of the pop-up like arrays affecting the Decumanus maximus, the anomalous counter-slope upthrusting of their broken flagstones, and the general southwards collapse of 
the Basilica Columns, seem to indicate that ground shaking was initiated SW of the city, maybe along the offshore prolongation of the CdGF. In this sense, the directivity effect of an hypothetical sinistral NE-SW lineal source SW of the city should specifically amplify ground shaking at the Bolonia Bay area, even under the simplest assumptions for finite moving seismic sources in near-filed scenarios (Hirasawa and Stauder, 1965).

\section{Conclusions}

The analysis of the disturbed archaeological remains and urban geology of the ancient Roman city of Baelo Claudia indicates that the two recorded periods of abrupt city destruction (AD 40-60 and ca. AD 350-395) can be reasonably related to recurrent earthquake occurrence in the Gibraltar Strait. On the basis of the recorded deformations and the nature of related ground collapse phenomena the causative events should have a minimum peak intensity of IX-X MSK. Similar deformations, and/or archaeological anomalies, have been described for recent (Mariolakos et al., 1998) and ancient (Stiros, 1996) seismic events in the Eastern Mediterranean. Presented data suggest that moderate (ca. $5 \mathrm{mb}$ ) local seismicity on the offshore prolongation of close NE-SW active strike-slip faults (e.g. CdGF) can account better for the observed destruction than far away strong events as initially proposed by Menanteau et al. (1983). The application of the Spanish Seismic Code (NCS-94, 1995) indicates that peak ground horizontal accelerations between 0.15 and $0.20 \mathrm{~g}$ can affect the studied site, with dominant vibration periods of 0.20 to $0.59 \mathrm{~s}$. These values are usually associated to earthquake intensities of VII MSK, and are especially hazardous for low rise buildings (as is the case) close to the epicenter, but hardly can account for the observed level of destruction. To understand this severe level of destruction (IX-X MSK), specific ground site and (probably) directivity effects should conjugate to amplify ground shaking at the studied site, unnoticed in other ancient Roman sites of the zone. Whatever the case this value of intensity is oversized in relation the real size of the causative event.

Finally it is necessary to point out that the reported ground deformations and archeological disturbances, conjugate with the city history (building periods), strongly indicating the occurrence of recurrent seismic damage, equivalent to other cases in the Mediterranean (e.g. Stiros and Papageourgiu, 2001; Altunel et al., 2003). However the presented data are not conclusive and the earthquake problem (precise dates, location, size and even occurrence) is still an open debate for the studied site. Only future studies of historic or archaeological character will throw more light on this case. At the moment all the collected data strongly points to earthquake damage occurrence, especially for the second event of city destruction during the 4th Century AD.

\section{Acknowledgements}

This work has been supported by the 97-00 Project of the Fund. Ramón Areces, the Spanish DGES Projects BT-02/1065 and BT-02/1691 and by the Acciones Intergradas grant HA2004-0099. The authors are especially grateful to D. Antonio Alvarez Rojas, Director of the Archaeological Site of Baelo Claudia. The comments of S. Marco, U. Kafri and S. Stiros improved the original manuscript.

\section{References}

Alonso Villalobos, C., Gracia Prieto, F.J., Ménanteau, C., Ojeda Calvo, R., Benavente González, J., Martínez del Pozo, J.A., 2003. Paléogéographie de l'anse de Bolonia (Tarifa, Espagne) à l'époque romaine. Dynamiques environnementales et histoire en domaines méditerranéens (Université de Paris-Sorbonne, 24-26 avril 2002). Elsevier.

Altunel, E., Stewart, I., Barka, A., Piccardi, L., 2003. Earthquake faulting at the Ancient Cnidus, SW Turkey. Turk. J. Eart. Sci. $12,121-137$.

Benkhelil, J., 1977. Etude néotectonique de la terminaison occidentale des Cordillères Bètiques (Espagne). Thèse d'Etat, Univ. Nice, France.

Bolt, B.A., 1993. Earthquakes, 3rd edition. Freeman \& Co., New York.

Borja, F., Martínez, A., Troya, A., 1993. El proceso histórico de destrucción de la ciudad Romana de Baelo Claudia (SW Cádiz): Caracterización geotécnica y análisis de formaciones superficiales. Arqueol. Espac. 16/17, 297-308.

Borja, F., Zazo, C., Dabrio, C.J., Díaz del Olmo, F., Goy, J.L., Lario, J., 1999. Holocene aeolian phases and human settlements along the Atlantic coast of southern Spain. Holocene 9 (3), 333-339.

Bost, J.P., Chaves, F., Defeyrot, G., Hiernard, J., Richard, J.C., 1987. Belo IV: Les monnaines. Pub. Casa de Velazquez, Serie Archeologie 6. Ed. Broccard, París. 
Bourgeois, A., Mayet, F., 1991. Belo VI : Les sigillées. Pub. Casa de Velazquez, Serie Archeologie 10. Ed. Broccard, París.

Coburn, A., Spence, R., 1992. Site selection and seismic hazard assessment. Earthquake, 187-213.

Didierjean, F., Lunais, S., Paulian, A., 1978. La douzième campagne de foullies de la Casa de Velazquez à Belo en 1977 (Bolonia, Cadix). Chro. Mél. Casa de Velazquez 14, 433-464.

Esposito, E., Porfido, S., Mastrolorenzo, G., Nikonov, A., Serva, L., 1997. Brief review and preliminary proposal for the use of ground effects in the macroseismic intensity assessment. Proc. 30th Int. Geol. Congress, vol. 5. VSP, Netherlands, pp. 233-343.

Esteras, M., Muñoz, P., Sandoval, N., 1988. Mapa Geológico del Estrecho de Gibraltar-Orilla Norte-Escala 1:100.000 ( $1^{\circ}$ Edición). SECEGSA, Madrid.

Galbis, R.J., 1932. Catálogo sísmico de la zona comprendida entre los meridianos $5^{\circ} \mathrm{E}$ y $20^{\circ} \mathrm{W}$ de Greenwich y los paralelos $45^{\circ}$ y $25^{\circ} \mathrm{N}$. Dirección General del Instituto Geográfico. Catastral y de Estadística, Madrid.

Galbis, R.J., 1932. Catálogo sísmico de la zona comprendida entre los meridianos $5^{\circ} \mathrm{E}$ y $20^{\circ} \mathrm{W}$ de Greenwich y los paralelos $45^{\circ}$ y $25^{\circ} \mathrm{N}$. Dirección General del Instituto Geográfico. Catastral y de Estadística, Madrid.

Goy, J.L., Zazo, Mörner, N.A., Hoyos, C., Somoza, M., Lario, L., Bardají, J., Silva, T., Dabrio, P.G., J.C., 1994. Pop up-like deformation of a Roman floor and liquefaction structures in SW Spain as possible paleoseismic indicators. Bull. INQUA N.C. $17,42-44$.

Goy, J.L., Zazo, C., Silva, P.G., Lario, J., Bardají, T., Somoza, L., 1995. Evaluación geomorfológica del comportamiento neotectónico del Estrecho de Gibraltar durante el Cuaternario. In: Esteras, M. (Ed.), El Enlace Fijo del Estrecho de Gibraltar, vol. 2. SECEGSA, Madrid, pp. 51-69.

Gracia, F.J., Benavente, J., 2000. Geomorfología de la costa atlántica gaditana. In: De Andrés, J.R., Gracia, F.J. (Eds.), Geomorfología Litoral, procesos activos, Monografías SEG, vol. 17. SEG, Madrid, pp. 235-255.

Gracia, F.J., Rodríguez Vidal, J., Benavente, J., Cáceres, L., López Aguayo, F., 1999. Tectónica Cuaternaria en la Bahia de Cádiz. In: Pallí, L., Roqué, C. (Eds.), Avances en el estudio del Cuaternario español. AEQUA-UdG, Girona, España, pp. 67-74.

Guidoboni, E., Comastri, A., Traina, G., 1994. Catalogue of Ancient Earthquakes in the Mediterranean Area Up to the 10th Century. Institute Nazionale di Geofisica, Rome.

Hancock, P.L., Altunel, E., 1997. Faulted archaeological relicts at Hierapolis (Pammukale), Turkey. J. Geodyn. 24, 21-36.

Hatzfeld, D., 1976. Etude de seismicité dans la region de l'arc de Gibraltar. Ann. Géophys. 32 (1), 71-85.

Hirasawa, T., Stauder, W., 1965. On the seismic body waves from a finite moving source. Bull. Seismol. Soc. Am. 55, $237-262$.

Hoyos, M., Sánchez-Moral, S., Sanz-Rubio, E., Cañaveras, J., 1999. Causas y mecanismos de deterioro de los materiales petreos del pavimento del conjunto arqueológico de Baelo Claudia (Cádiz, Spain). Mat. Construcción 49 (255), 5-18.

IGN, 1994. Banco de Datos Sísmicos, Servicio Nacional de Sismología. Instituto Geográfico Nacional (IGN), Madrid. Petición de datos n 94/0001 (Data-file).
Karcz, I., Kafri, U., 1978. Evaluation of supposed archaeoseismic damage in Israel. J. Archaeol. Sci. 5, 237-253.

Liu, L., Makris, J., 1995. Seismicity and deformation around the Gibraltar arc. In: Esteras, M. (Ed.), El Enlace Fijo del Estrecho de Gibraltar, vol. 2. SECEGSA, Madrid, pp. 323-330.

Makris, J., Egloff, E., 1993. Seismic and seismicity study of the Gibraltar Stratir. Unpublished Report. SECEGSA-SNED Gibraltar Strait Project. Unv. Harmburg, Germany.

Marco, S., Agnon, A., Ellenblum, R., Eidelman, A., Basson, U., Boas, A., 1997. 817-year old walls offset sinistrally $2.1 \mathrm{~m}$ by the Dead Sea Transform, Israel. J. Geodyn. 24, 11-20.

Mariolakos, I., Fountoulis, I., Mariolakos, D., 1998. Pop-up like deformation seismic structures at the northwestern coast of the Gulf of Corinth (Greece) induced by the Egion earthquake of 15-6-95. Abstracts with programs 8th IAG Congress, Vancouver, Canada.

Martínez Solares, J.M., López Arroyo, A., Mezcua, J., 1979. Isoseismal map of the 1755 Lisbon earthquake obtained from Spanish data. Tectonophysics 53, 301-313.

Menanteau, L., Vanney, J.R., Zazo, C., 1983. Belo II : Belo et son environment (Detroit de Gibraltar), Etude physique d'un site antique. Pub. Casa de Velazquez, Serie Archeologie 4., Ed. Broccard, París.

Meghraoui, M., 2002. Palaeoseismology and archeoseismology along the Dead Sea fault in Syria: earthquake faulting and potential for a completed historical seismicity catalogue. In: Leroy, S., Stewart, I.S. (Eds.), Environmental Catastrophes and Recovery in the Holocene Abst. Vol. Brunel University, West London (UK), p. 58.

Michetti, M., Ferreli, L., Esposito, E., Porfido, S., Blumetti, A.M., Vittori, E., Serva, L., Roberts, G.P., 2000. Ground effects during the 9 September 1988, Mw=5.6, Lauria Earthquake and the seismic potential of the "Aseismic" Pollino region in southern Italy. Seismol. Res. Lett. 71, 31-46.

NCS-94, 1995. Norma de Construcción Sismo-Resistente Española. Normativa de Acciones en la Edificación AE-88 (NBE) Serie Normativas. Ministerio de Fomento, Madrid, España, p. 235.

Sillières, P., 1995. Le Capitole de Baelo Claudia: Un cas d'incohérence de datations archéologique et stylistique et un exemple de solution. Annas 7/8, 285-298.

Sillières, P., 1997. Baelo Claudia: Una ciudad Romana de la Bética. Junta de Andalucía- Casa de Velázquez, Madrid.

Similox-Tohon, D., Sintuvin, M., Fernández, M., Muchez, P., Waelkens, M., 2002. Active normal faults near the ancient city of Sagalassos (SW Turkey) revealed by geomorphological features and drainage patterns using satellite images and digital elevation model. In: Leroy, S., Stewart, I.S. (Eds.), Environmental Catastrophes and Recovery in the Holocene Abst. Vol. Brunel University, West London (UK), pp. 78-79.

Serva, L., 1994. Ground effects in intensity scales. Terra Nova 6, 414-416.

Stahl, P., 1971. La séismicité de Tanger et de sa région. Notes Mem. Serv. Geol. Maroc 22, 101-109 (bis).

Stiros, S., 1988. Archaeology: a tool to study active tectonics - the Aegean as a case study. Eos Trans. Am. Geophys. Union 13, 1636-1639. 
Stiros, S., 1996. Identification of earthquakes from archaeological data: methodology, criteria and limitations. In: Stiros, S., Jones, R.E. (Eds.), Archaeoseismology Ocassional Paper no 7 of the Fitch Laboratory. Bristish School at Athens, Athens, pp. 129-152.

Stiros, S., 2001. The AD 365 Crete earthquake and possible seismic clustering during the fourth to sixth centuries $\mathrm{AD}$ in the Eastern Mediterranean: a review of historical and archaeological data. J. Struct. Geol. 23, 545-562.

Stiros, S., Papageourgiu, S., 2001. Seismicity of western Crete and the destruction of the town of Kisamos at AD 365: archaeological evidence. J. Seismol. 5, 381-397.

Vorsevi S.A., 1993. Reconocimiento geotecnico de las ruinas
Romanas de Baelo Claudia, Tarifa. Unpublished Report, Sevilla, Spain. p. 49.

Vorsevi S.A., 1995. Complemento al reconocimiento geotecnico de las ruinas Romanas de Baelo Claudia, Tarifa. Unpublished Report, Sevilla, Spain. p. 27.

Westaway, R., 1990. Present-day kinematics of the plate boundary between Africa and Europe, from Azores to the Aegean. Earth Planet. Sci. Lett. 96, 393-406.

Zazo, C., Silva, P.G., Goy, J.L., Hillaire-Marcel, C., Lario, J., Bardají, T., González, A., 1999. Coastal uplift in continental collision plate boundaries: data from the Last interglacial marine terraces of the Gibraltar Strait area (south Spain). Tectonophysics $301,95-119$. 